\title{
MICROSOFT FORM: ANGKET, FORMULIR, DAN KUIS SECARA DARING
}

\author{
Eric Kunto Aribowo, S.S., M.A.
}

\section{APA ITU FORM?}

Microsoft Form adalah sebuah layanan daring yang dapat digunakan untuk mengumpulkan jajak pendapat (polling, survei) dan kuis (dengan penilaian otomatis).

\section{APA MANFAAT FORM?}

Dengan memanfaatkan Form, kita dapat menghemat biaya, waktu, dan tenaga yang kita keluarkan apabila menggunakan kertas dengan sistem manual

(datang, bagikan, ambil, input data).

\section{LANGKAH-LANGKAH MEMPRODUKSI FORMULIR DAN KUIS MEMANFAATKAN FORM}

1. Kunjungi laman https://portal.office.com kemudian masukkan akun dan sandi pengaman

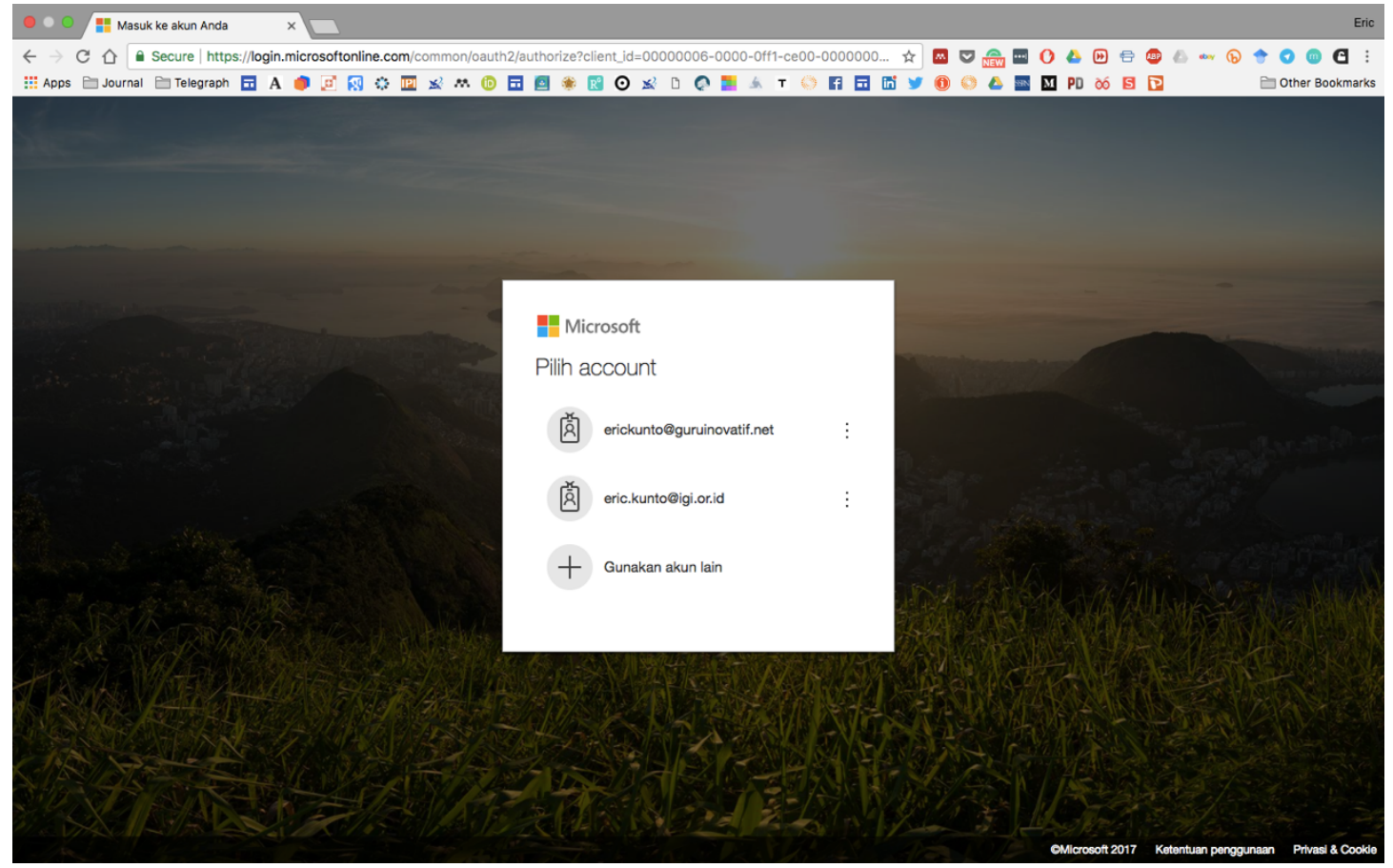


2. Pilih aplikasi Form (dengan logo huruf F)

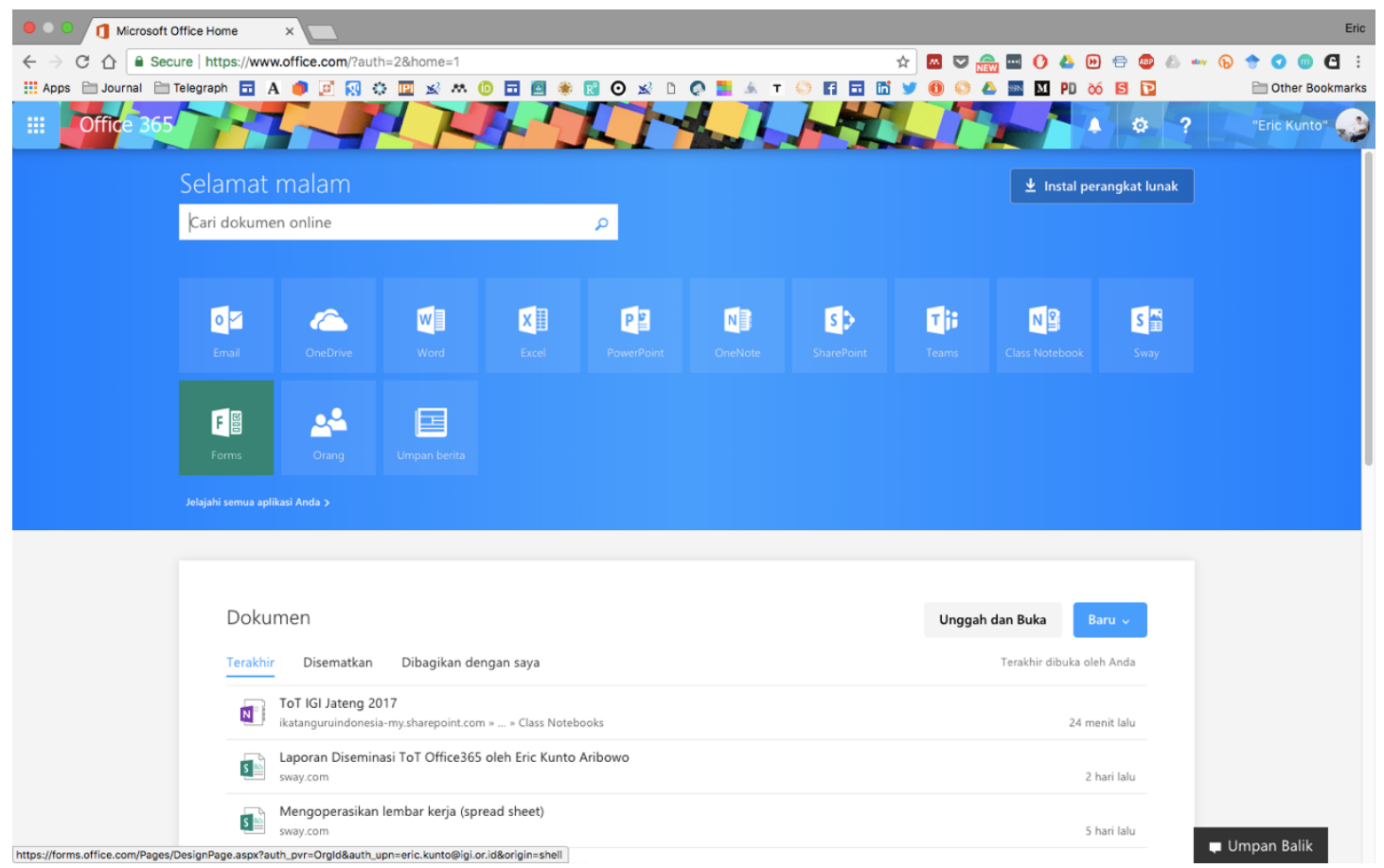

3. Apabila Anda pernah membuat formulir sebelumnya, maka akan tercantum sebagaimana contoh di bawah (formulir yang telah Anda buat akan ditampilkan). Apabila Anda belum pernah membuat formulir, maka tampilan akan kosong.

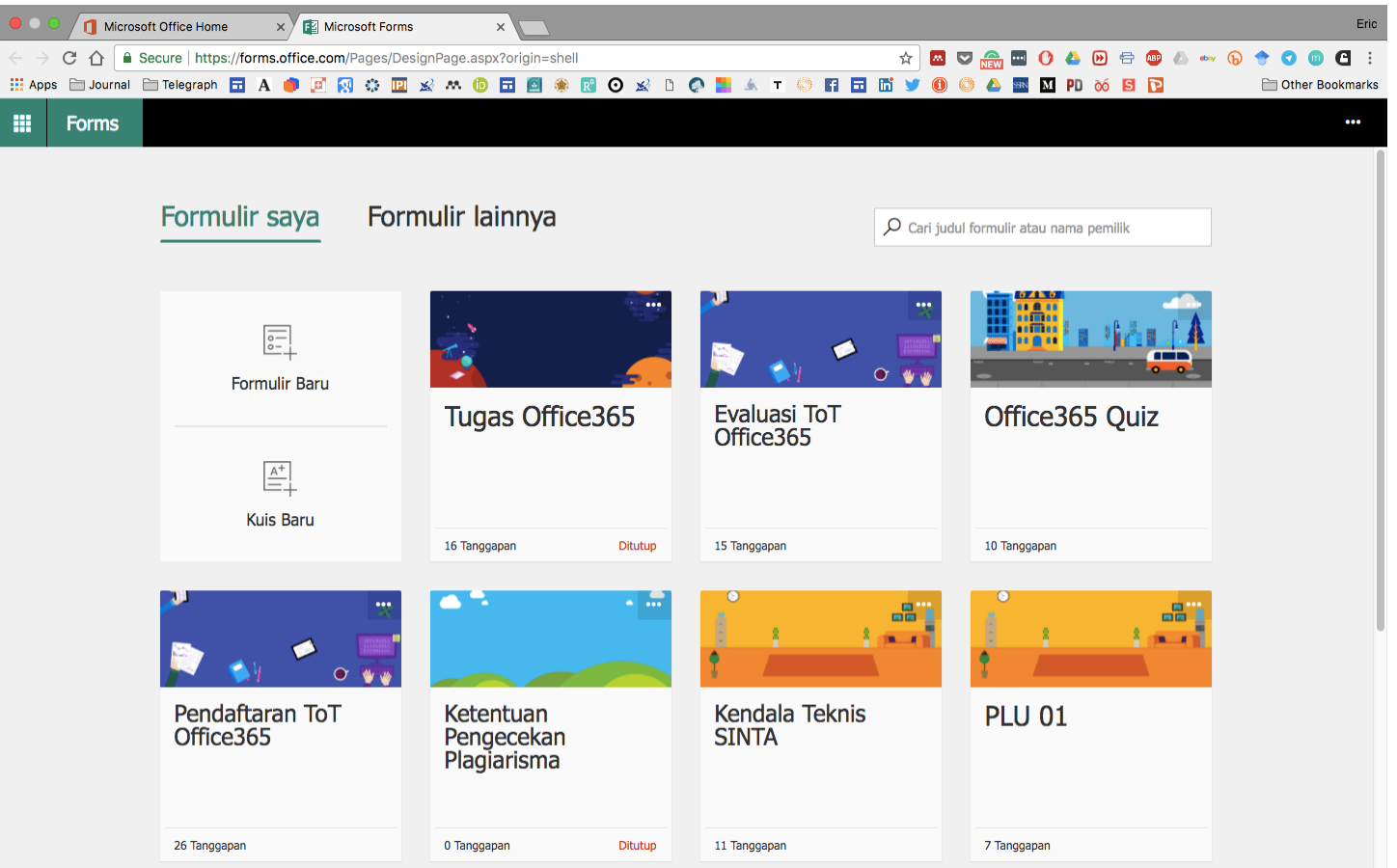


4. Untuk membuat Formulir, silakan klik "Formulir Baru". Apabila ingin membuat Kuis, silakan klik "Kuis Baru" maka tampilan akan berganti menjadi seperti tampak pada gambar berikut.

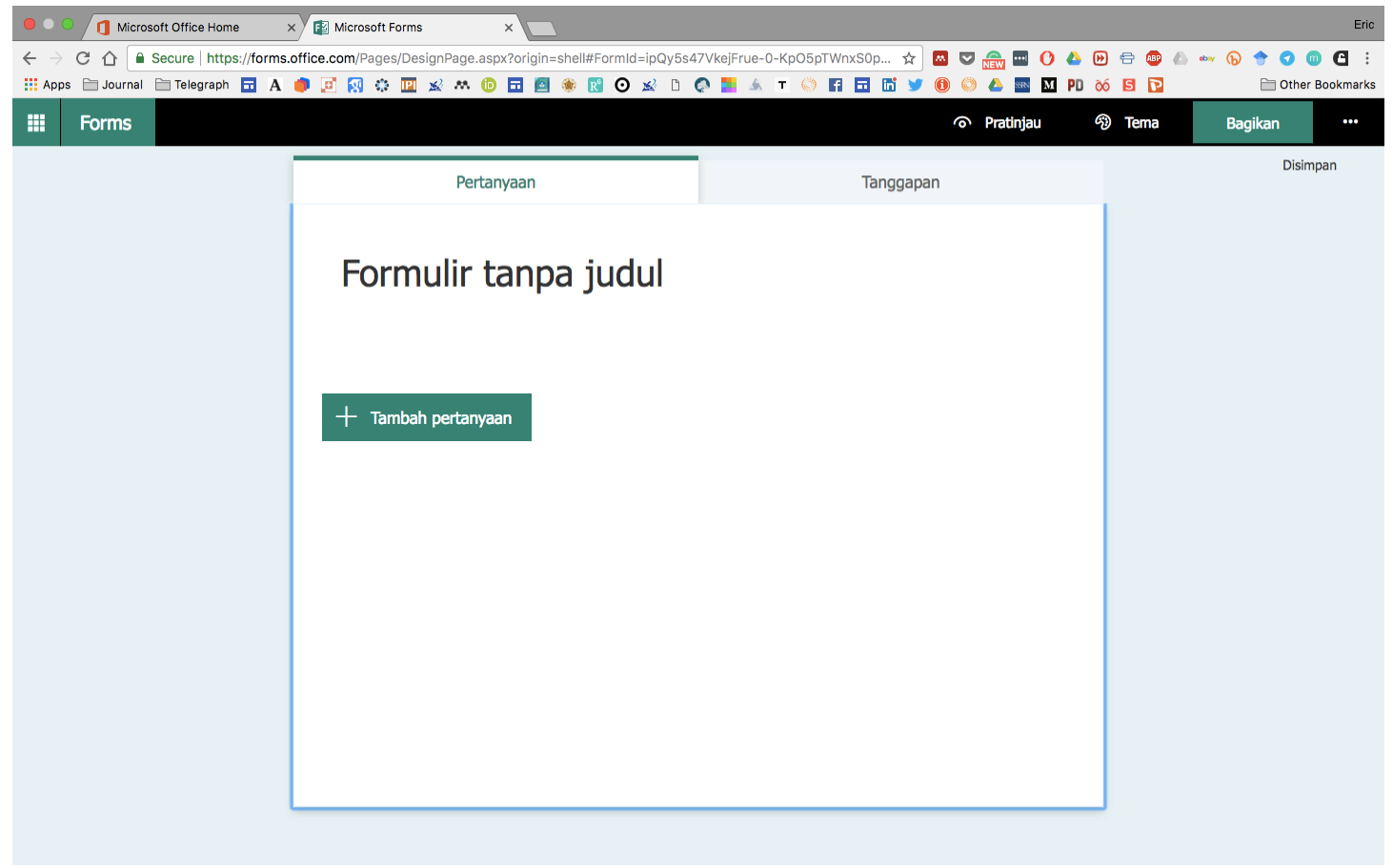

5. "Pratinjau" untuk melihat atau mengecek hasil jadi formulir, "Tema" untuk memilih warna dan corak tampilan, "Bagikan" untuk menyebarluaskan formulir secara daring, dan "Opsi" (tiga titik horisontal) untuk pengaturan lebih lanjut.

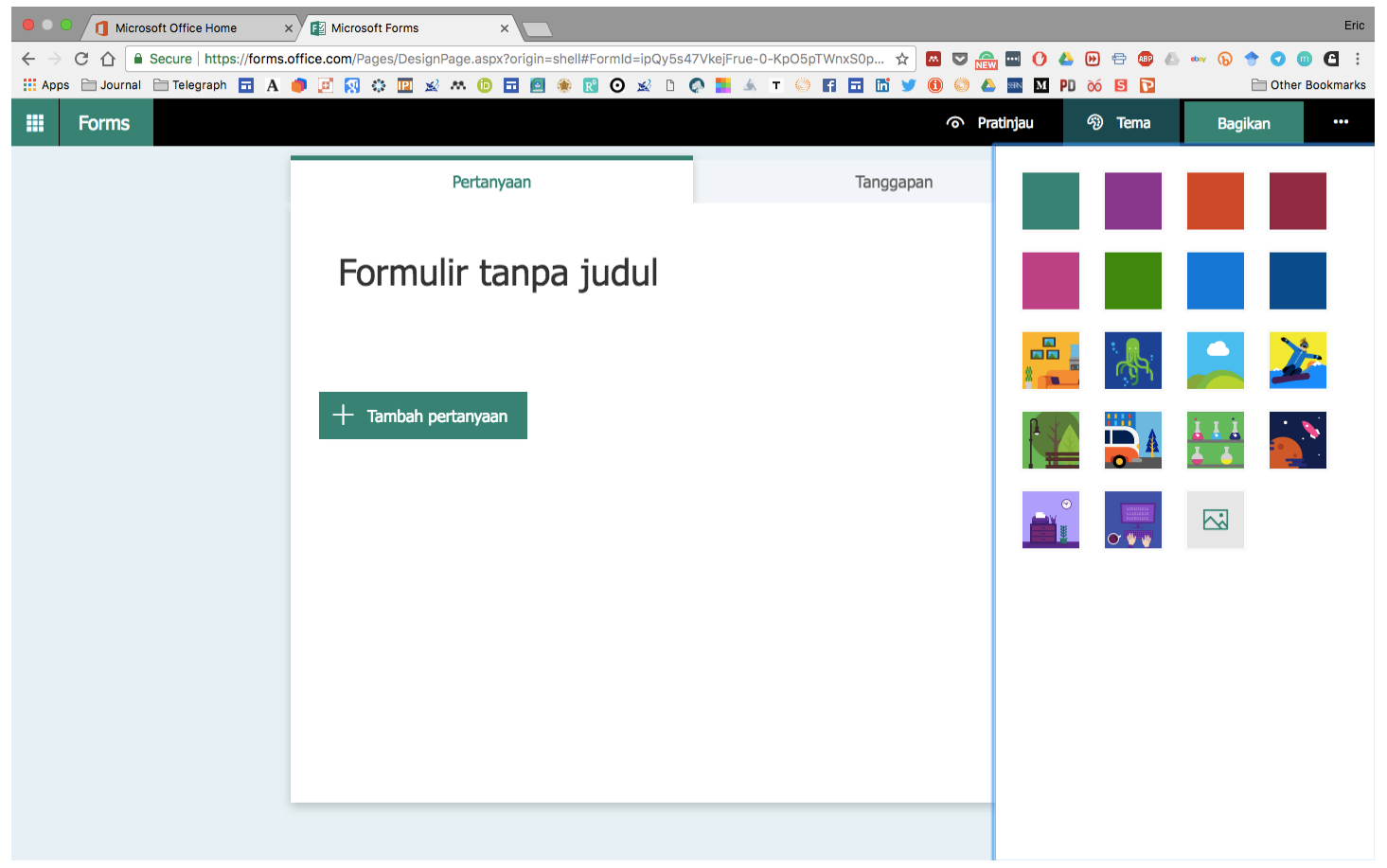


6. Untuk opsi akan muncul pilihan "Pencabangan" (apabila ada pertanyaan yang dapat diloncati, ketika ada beberapa kondisi prasyarat) dan "Pengaturan".

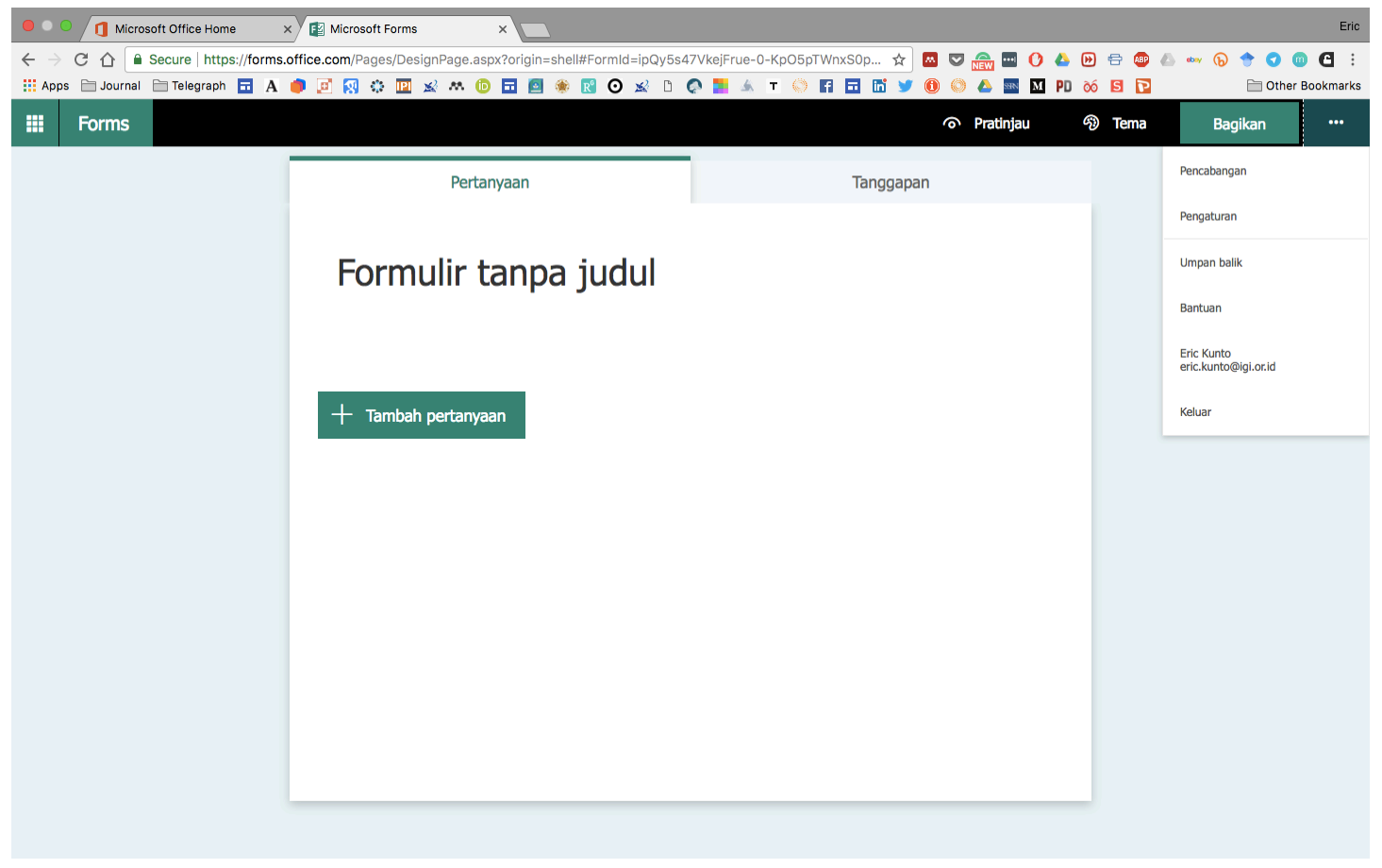

7. Pada opsi "Pengaturan" terdapat pilihan untuk membatasi responden (blok pertama) dan memilih tanggal mulai dan selesai; acak pertanyaan, menutup jajak pendapat (blok kedua).

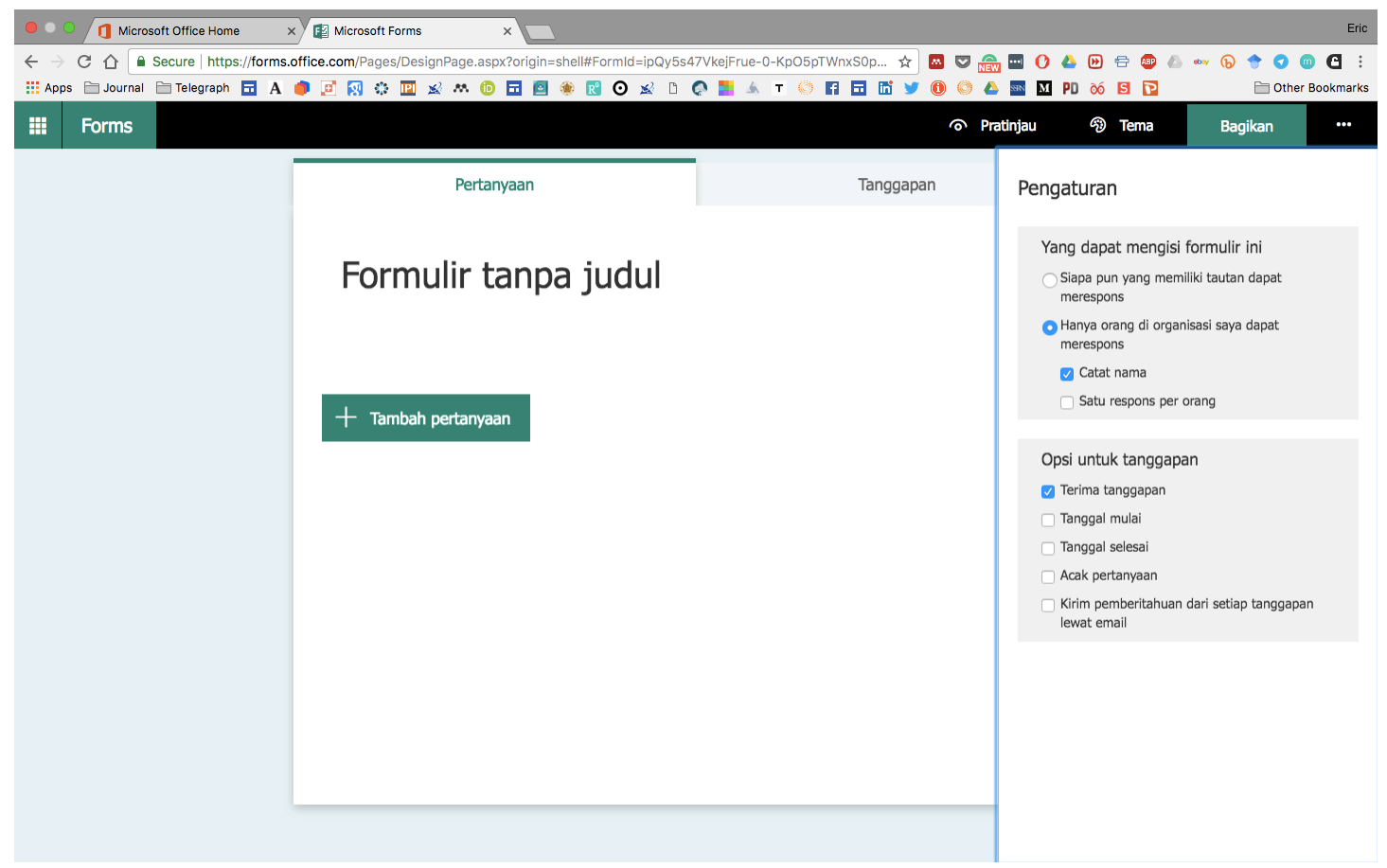


8. Masukkan judul formulir seperti yang Anda inginkan. Anda dapat menyisipkan gambar dengan memanfaatkan menu "Sisipkan gambar" (ikon gambar yang terletak di sebelah kanan judul formulir).

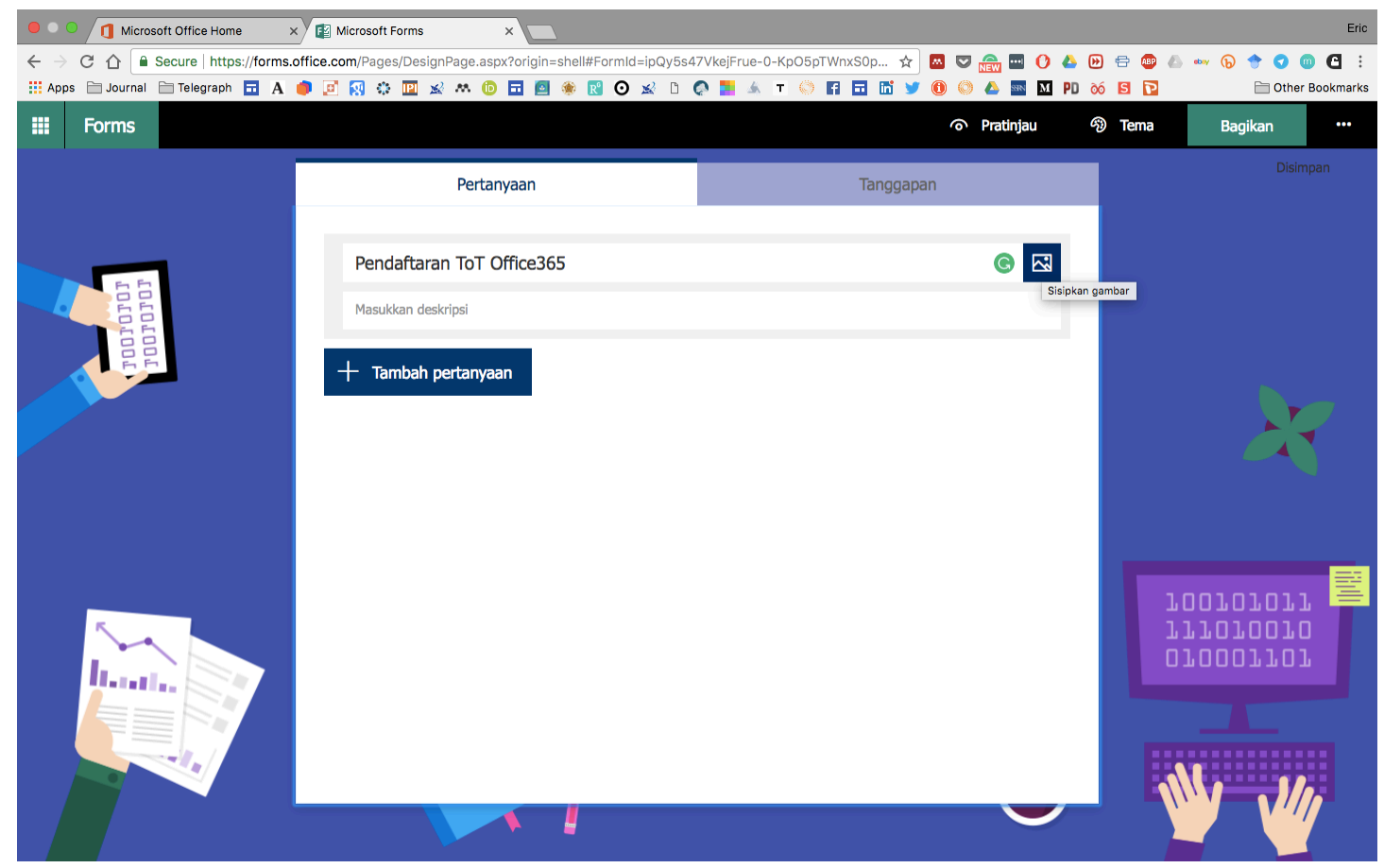

9. Secara otomatis, sistem akan mengarahkan pengguna ke mesin pencari "Bing". Masukkan kata kunci yang Anda inginkan. Pilih gambar yang Anda sukai, lalu klik "Tambahkan"

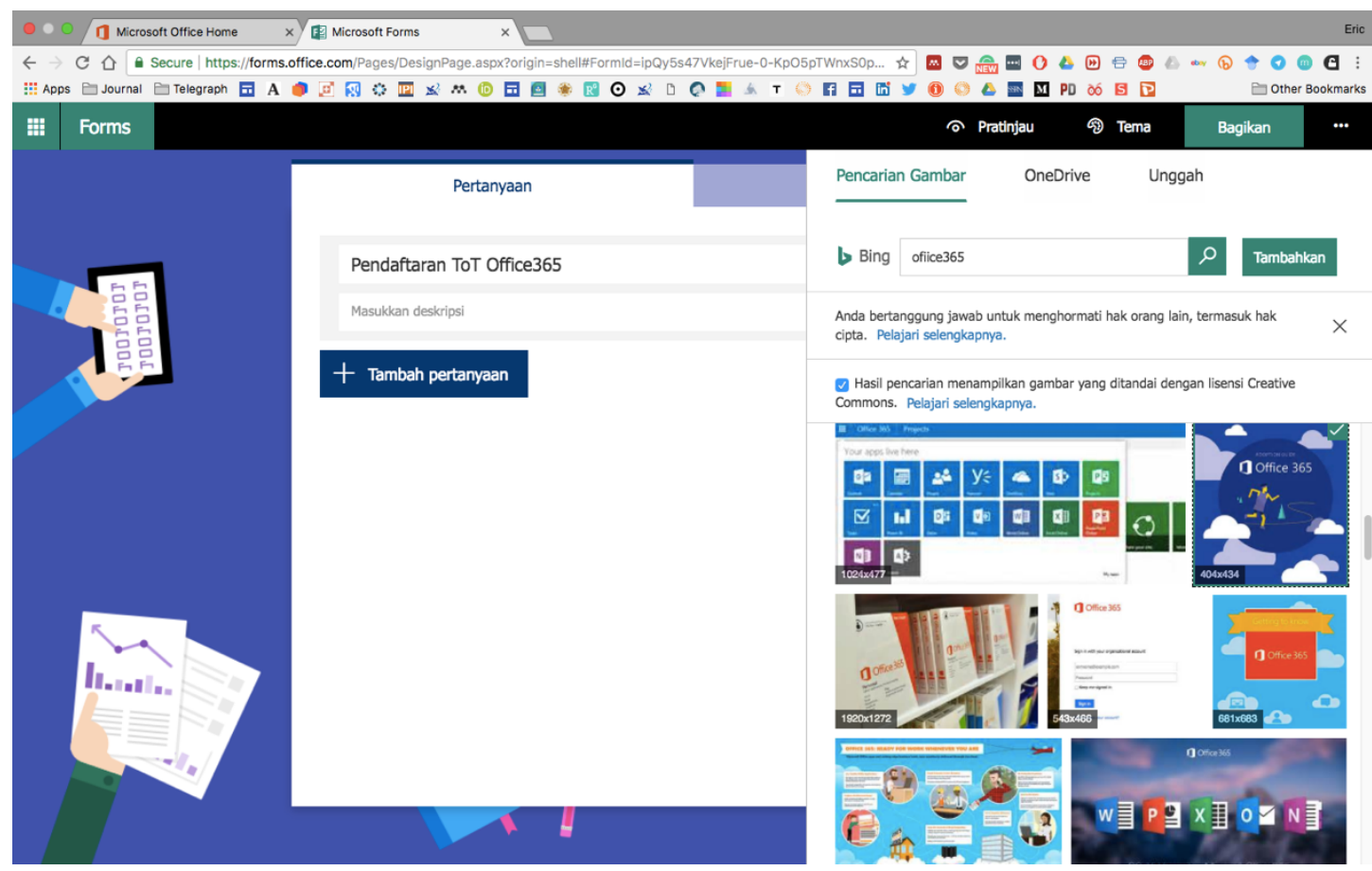


10. Gambar akan berada di samping kiri judul formulir. Anda dapat melakukan langkah serupa apabila ingin menambahkan gambar pada pertanyaan atau isian yang telah Anda siapkan.

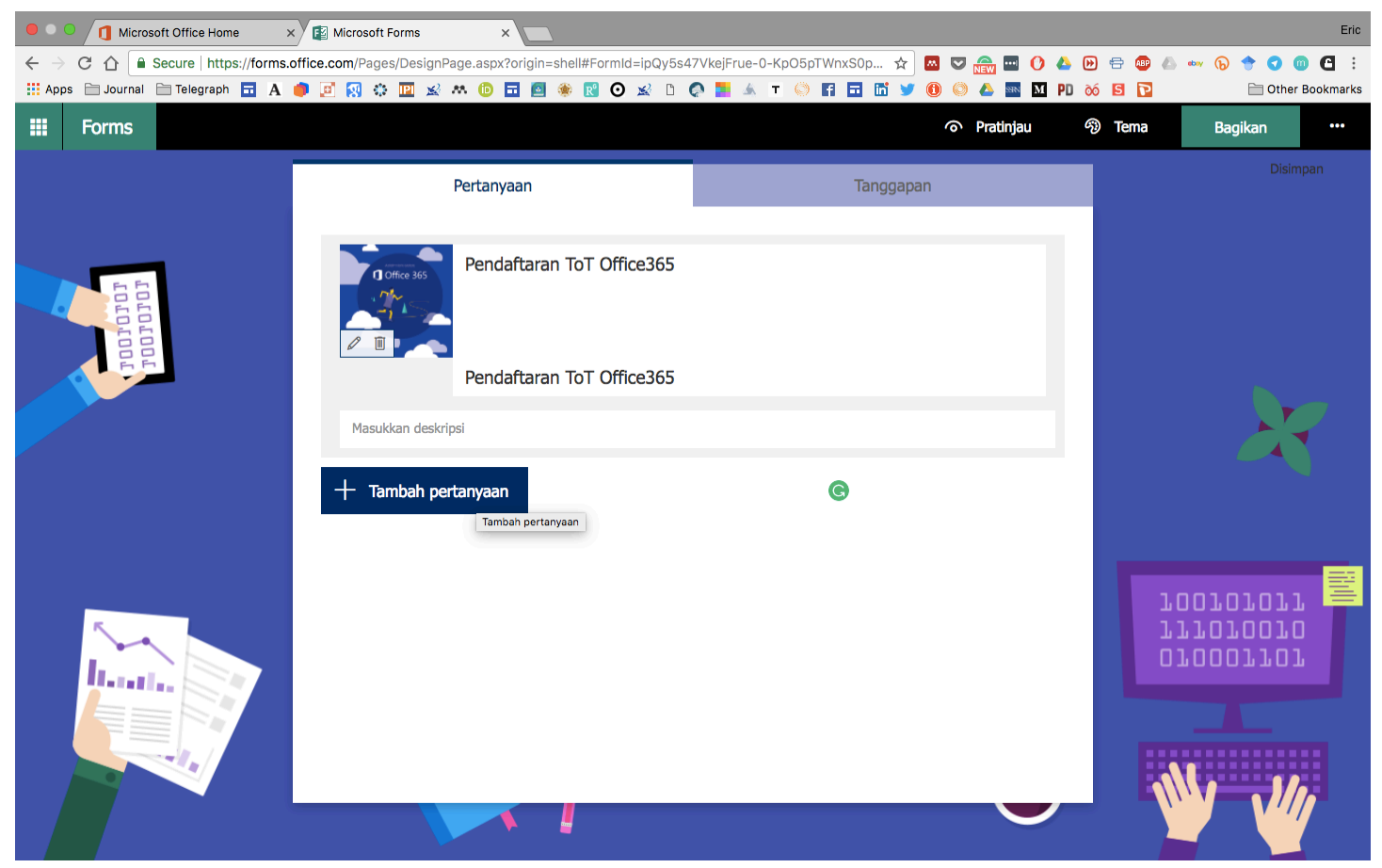

11. Secara default, Form menyediakan 5 bentuk atau tipe pertanyaan: "Pilihan" (pilihan ganda atau beberapa pilihan sekaligus), "Teks", "Peringkat" (penilaian/skor), "Tanggal", dan "Peringkat" (urutan).

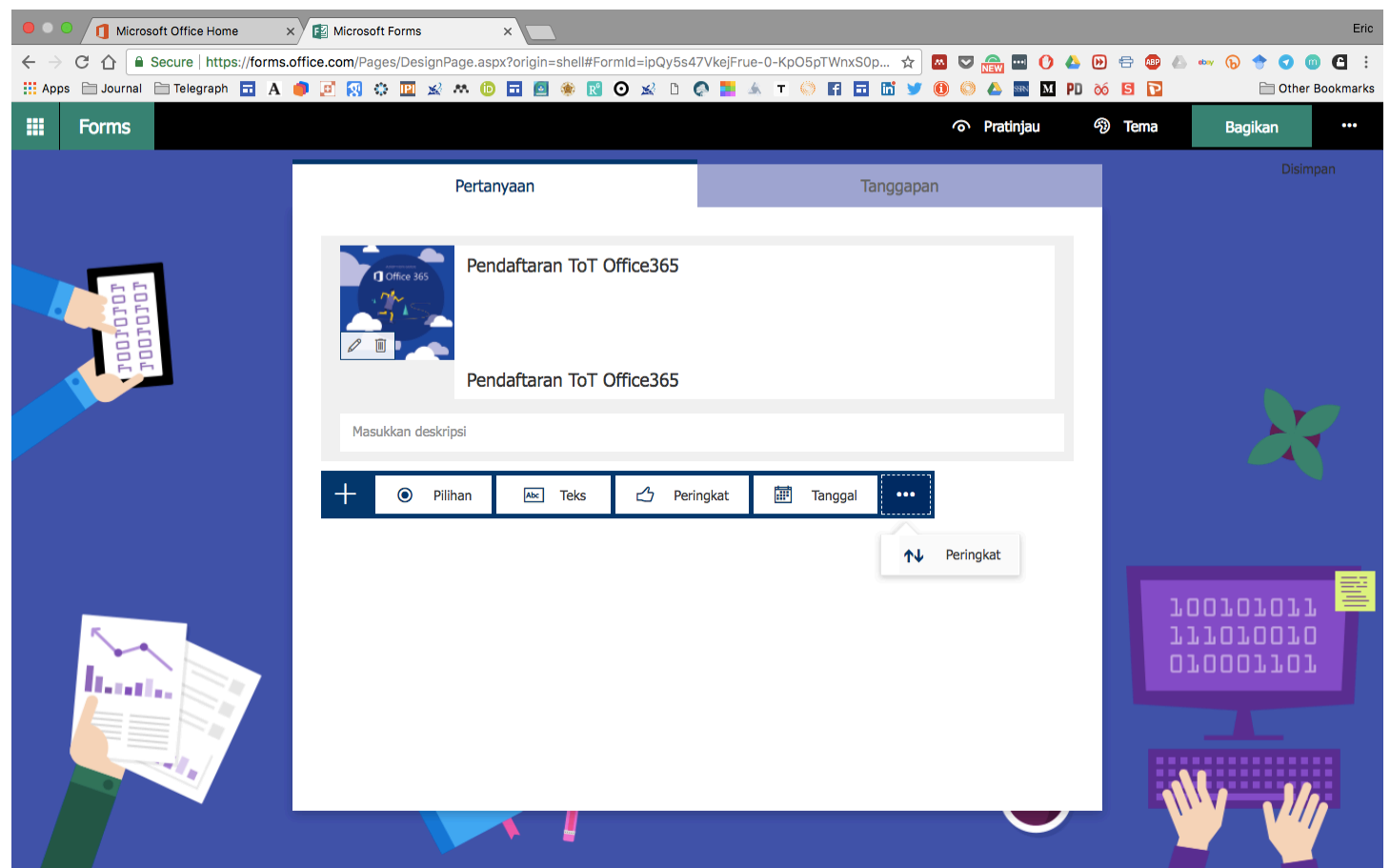


12. Sebagai contoh, saya ingin menambahkan input data berupa NAMA LENGKAP. Pilih "Tambah Pertanyaan" lalu pilih "Teks". Opsi "Jawaban panjang" dapat Anda pilih apabila ingin menyediakan jawaban teks yang lebih panjang (beberapa paragraf). Opsi "Harus diisi" apabila aktif, pengisi formulir harus mengisi jawaban (seluruh jawaban akan gagal dikirim apabila ditemukan ada "pertanyaan wajib" yang belum dijawab).

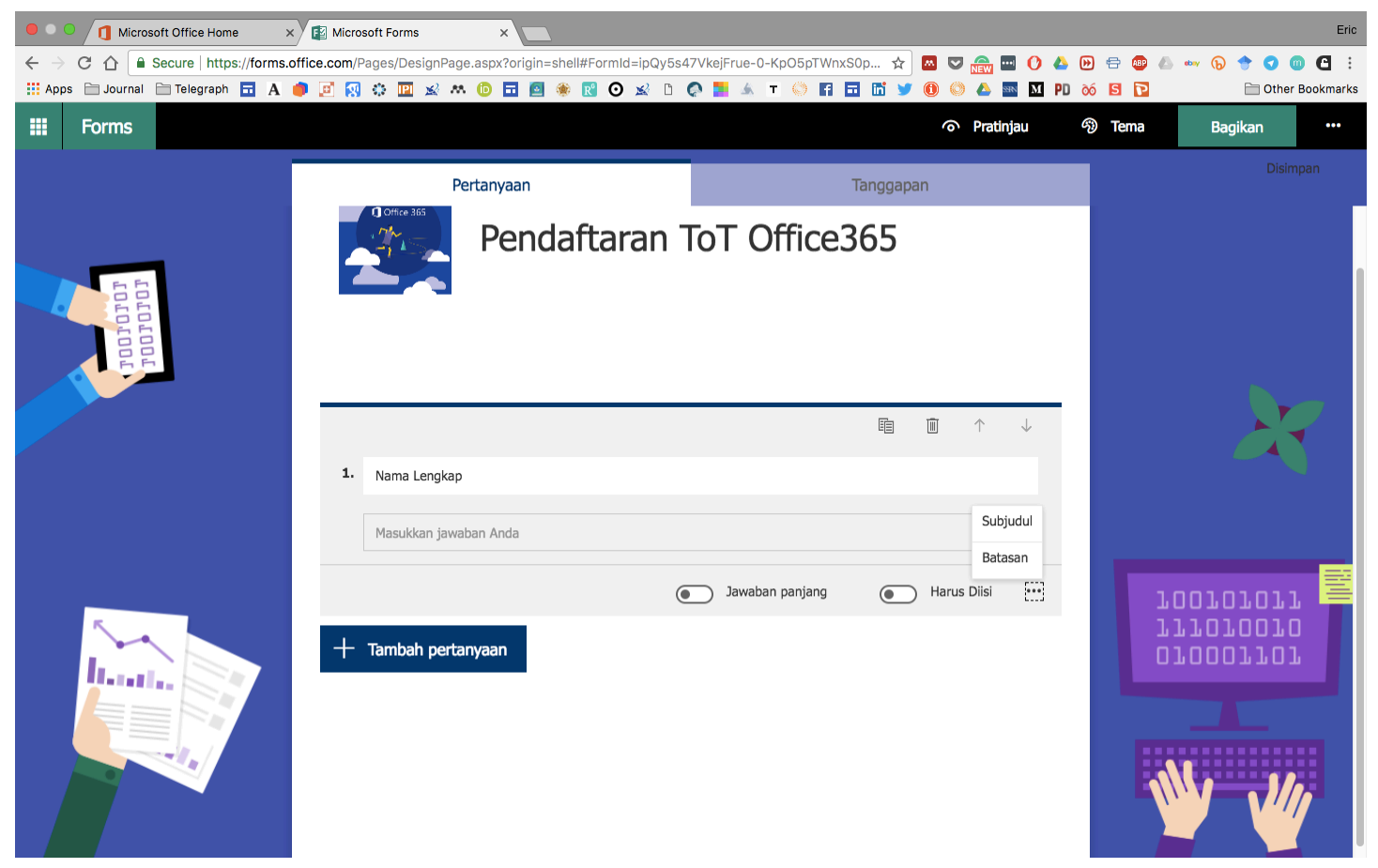

13. Lakukan hal serupa untuk tipe pertanyaan yang sama.

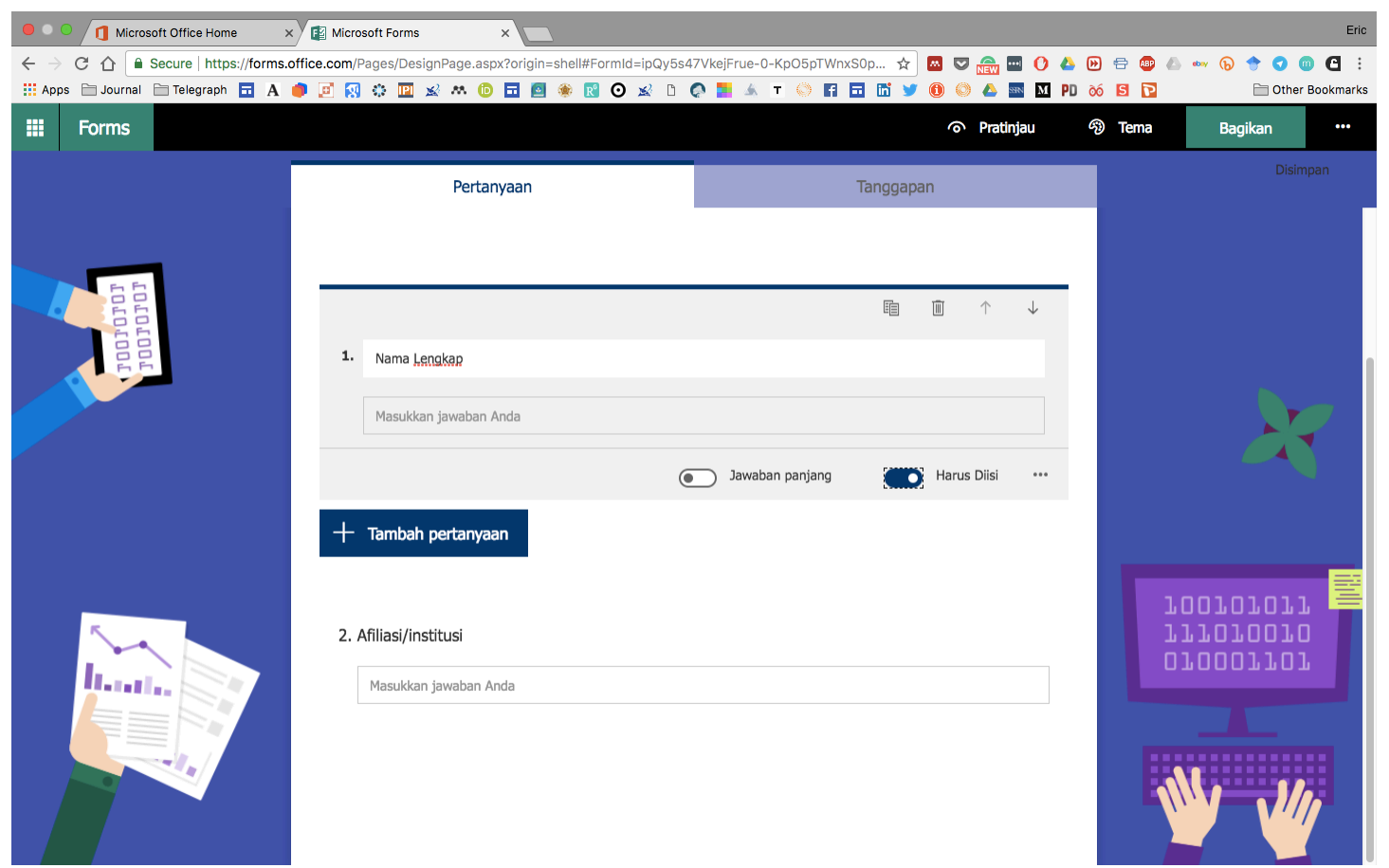


14. Pilih opsi "Pilihan" apabila Anda menginginkan pengisi formulir untuk menjawab dari beberapa pilihan yang Anda sediakan. Apabila "Jawaban ganda" diaktifkan, pengisi formulir dapat memilih beberapa jawaban sekaligus.

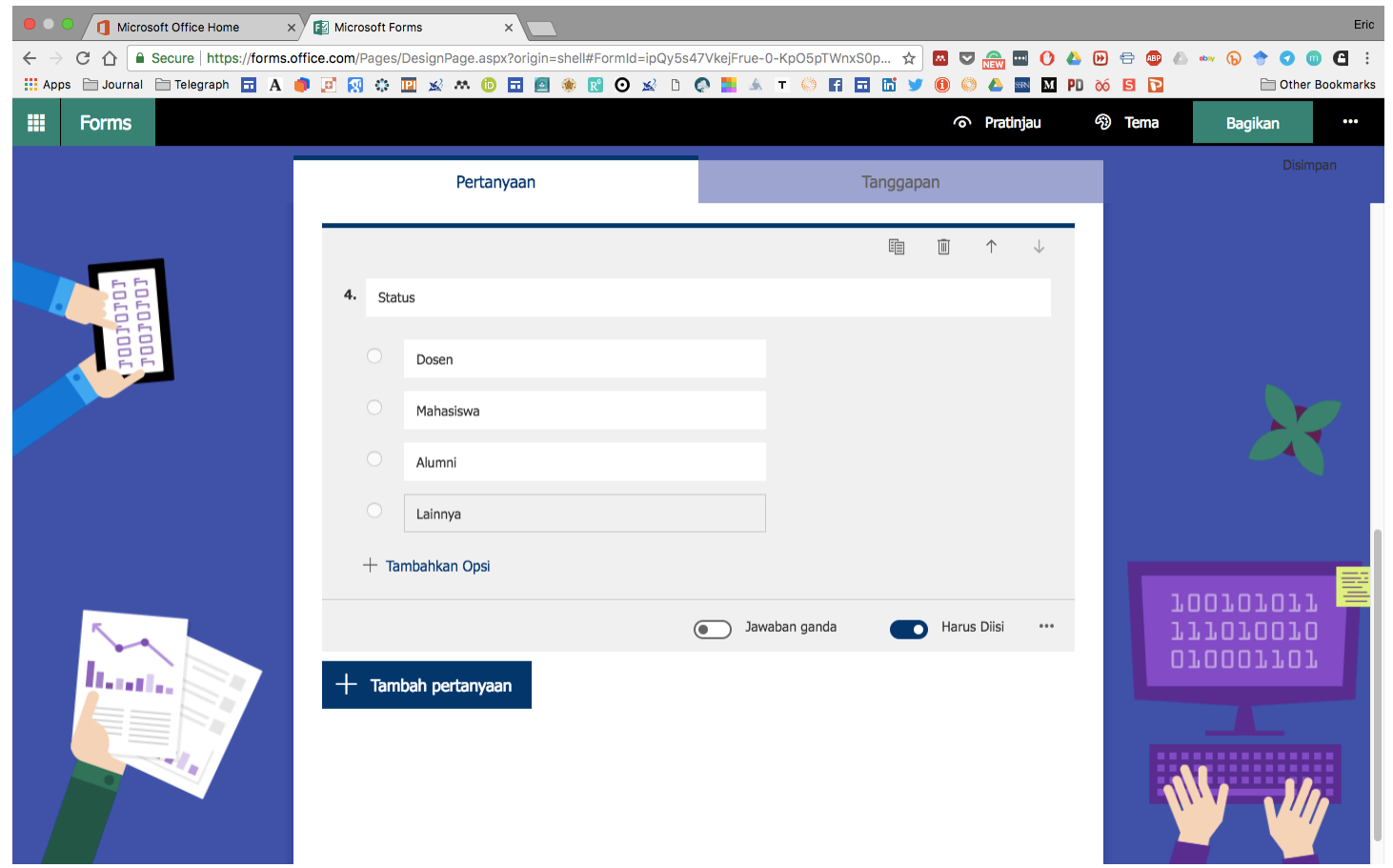

15. Tambahkan "Tanggal" apabila Anda menginginkan jawaban berupa tanggal tertentu, misalnya tanggal lahir.

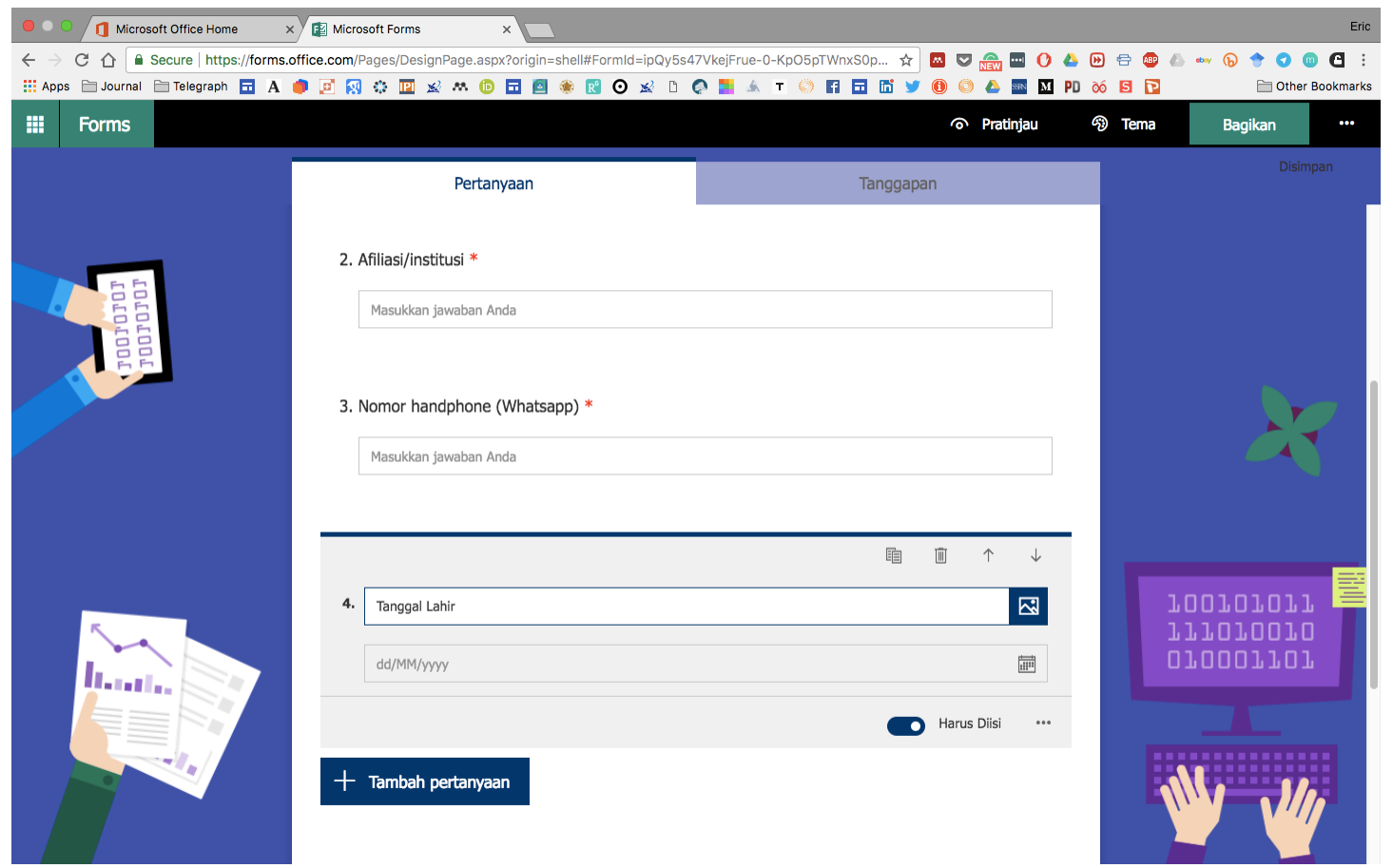


16. Opsi "Peringkat" digunakan apabila Anda menginginkan pengisi formulir untuk memberikan penilaian berdasarkan skor (bisa 5 atau 10). Anda dapat memilih penilaian dalam bentuk Bintang atau Angka.

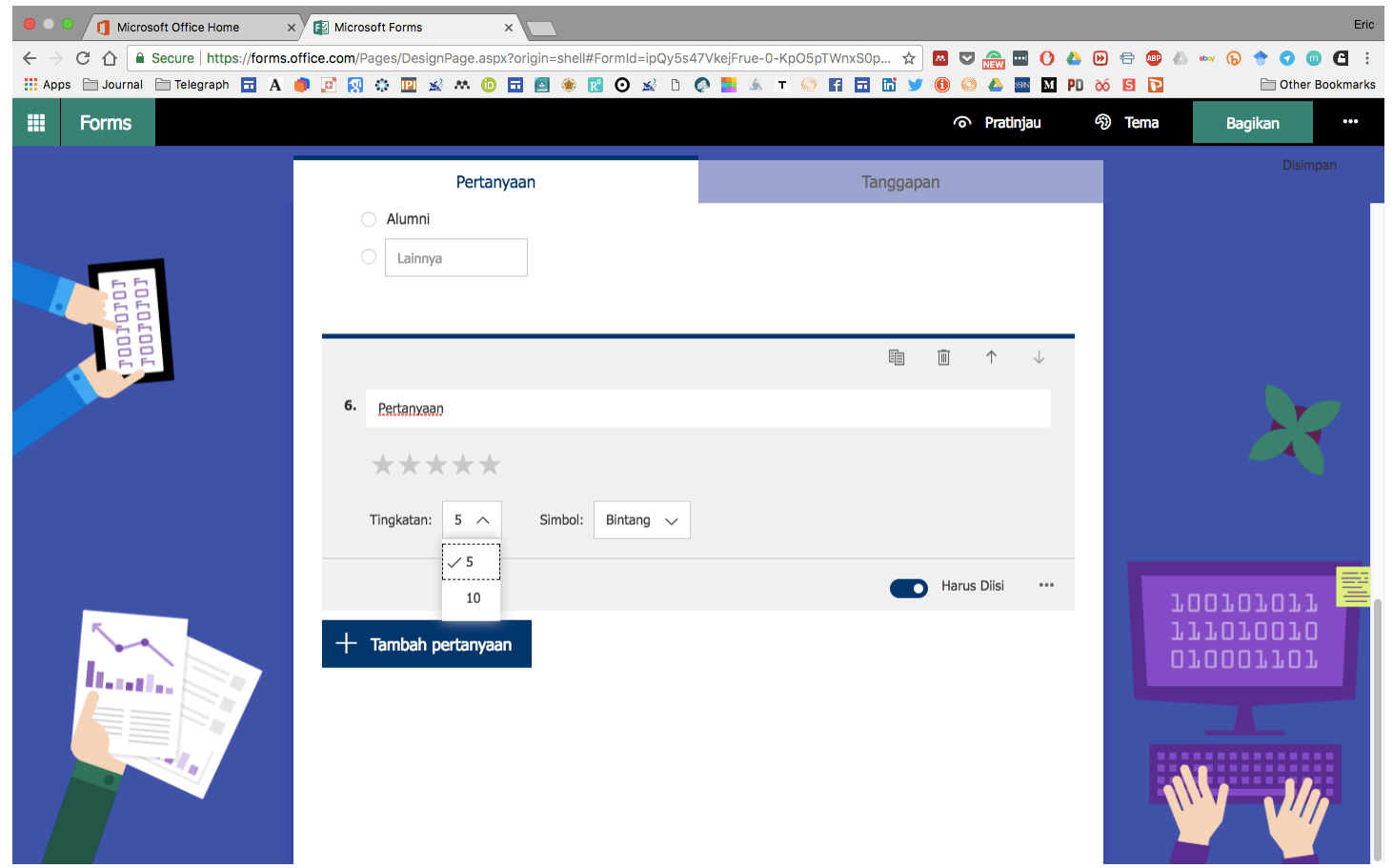

17. Opsi "Peringkat" dapat digunakan apabila Anda menanyakan sebuah urutan atau kronologis tertentu. Isikan jawaban sesuai urutan yang benar. Sistem akan mengacak pertanyaan pada responden secara otomatis.

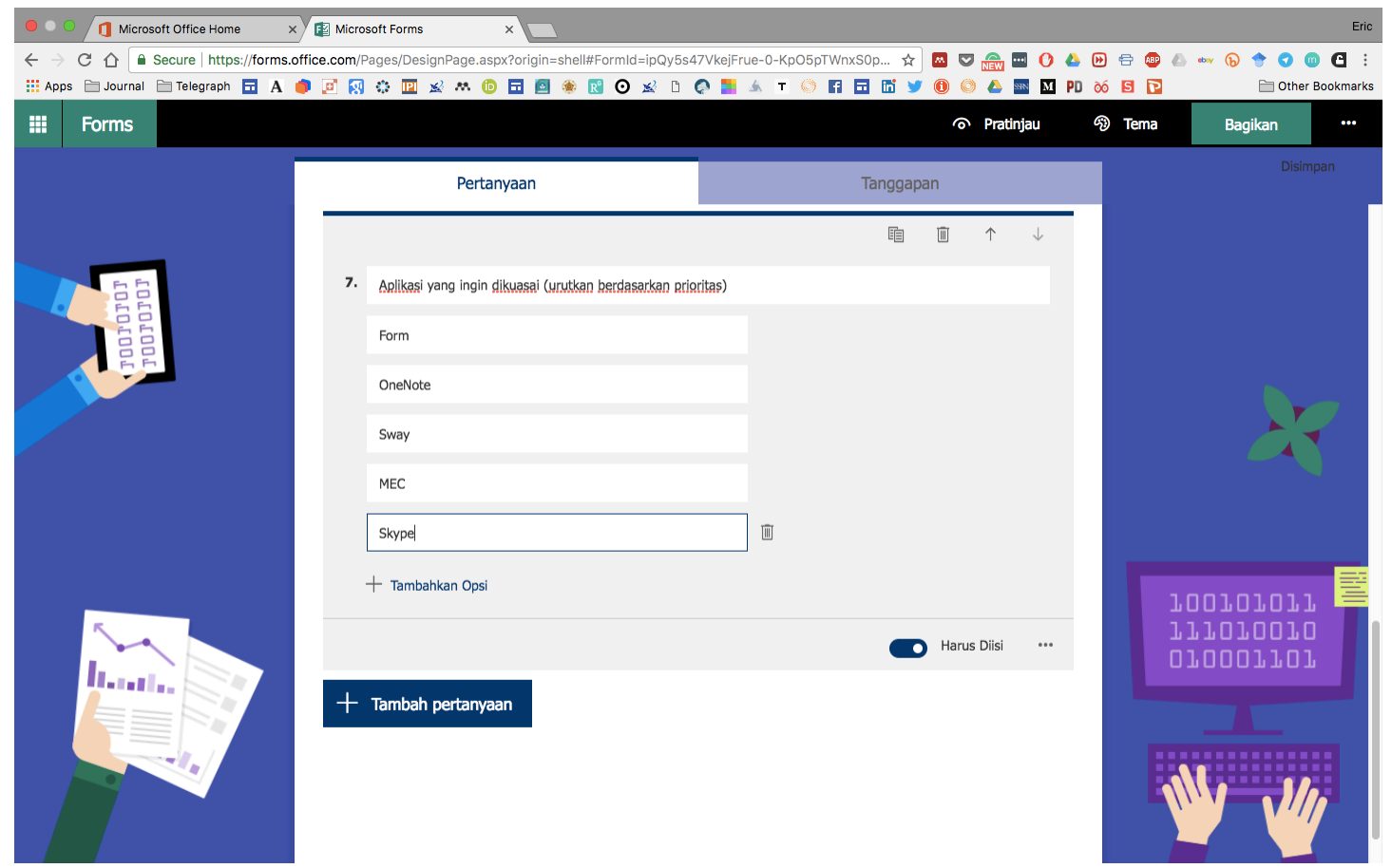


18. Apabila Anda telah selesai dalam membuat formulir lalu pilih "Bagikan" yang terletak di kanan atas. Anda dapat membagikan formulir ini dengan membagikan tautan (bisa dikirim melalui media sosial: Whatsapp, Facebook, dll; barcode; menyematkan pada blog atau situs; dan melalui email). Apabila Anda ingin mengajak rekan Anda untuk berkolaborasi (pertanyaan disusun oleh beberapa orang) manfaatkan fitur kolaborasi.

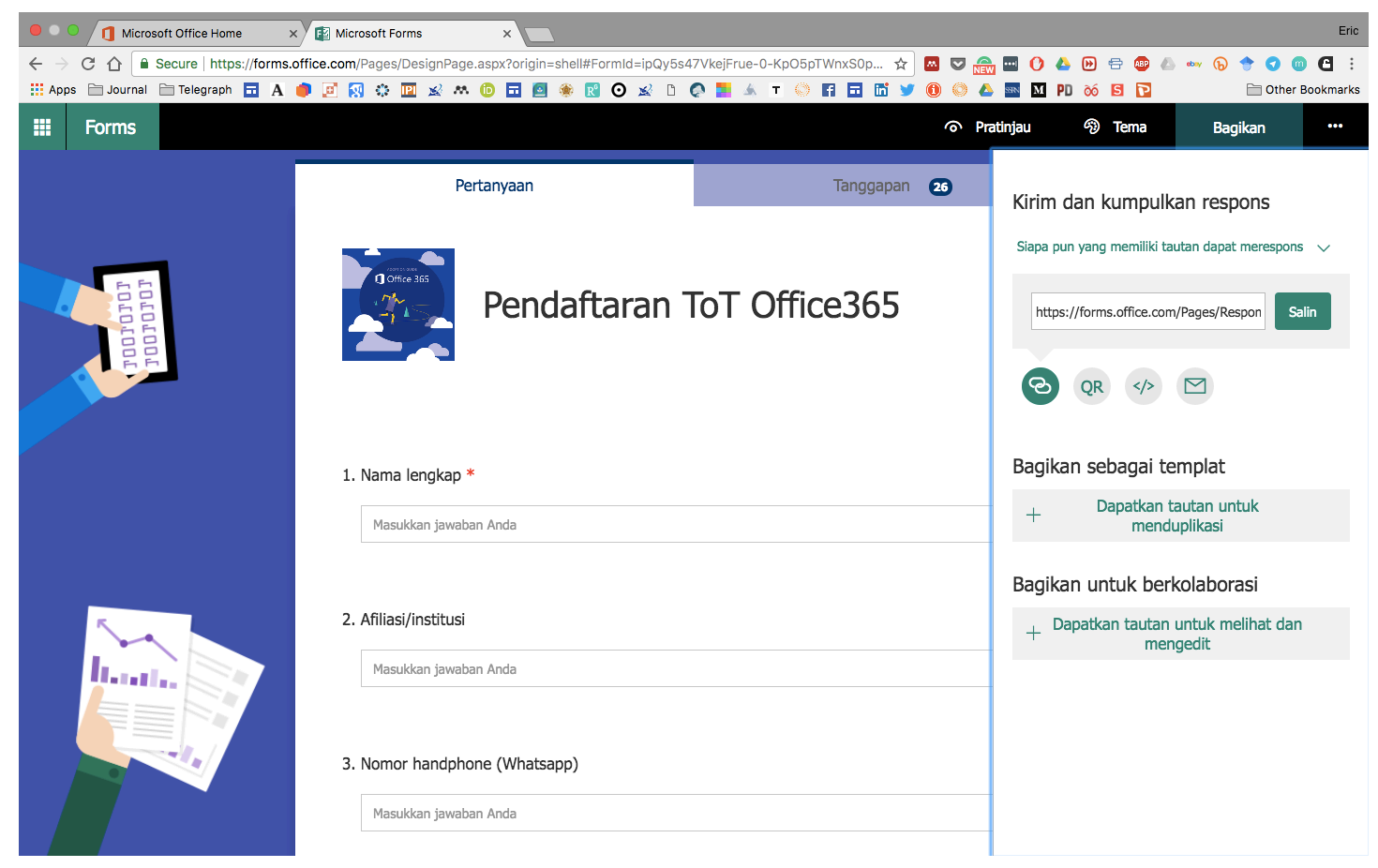

19. Seluruh tanggapan atau respon yang masuk akan terekam dalam "Tanggapan"

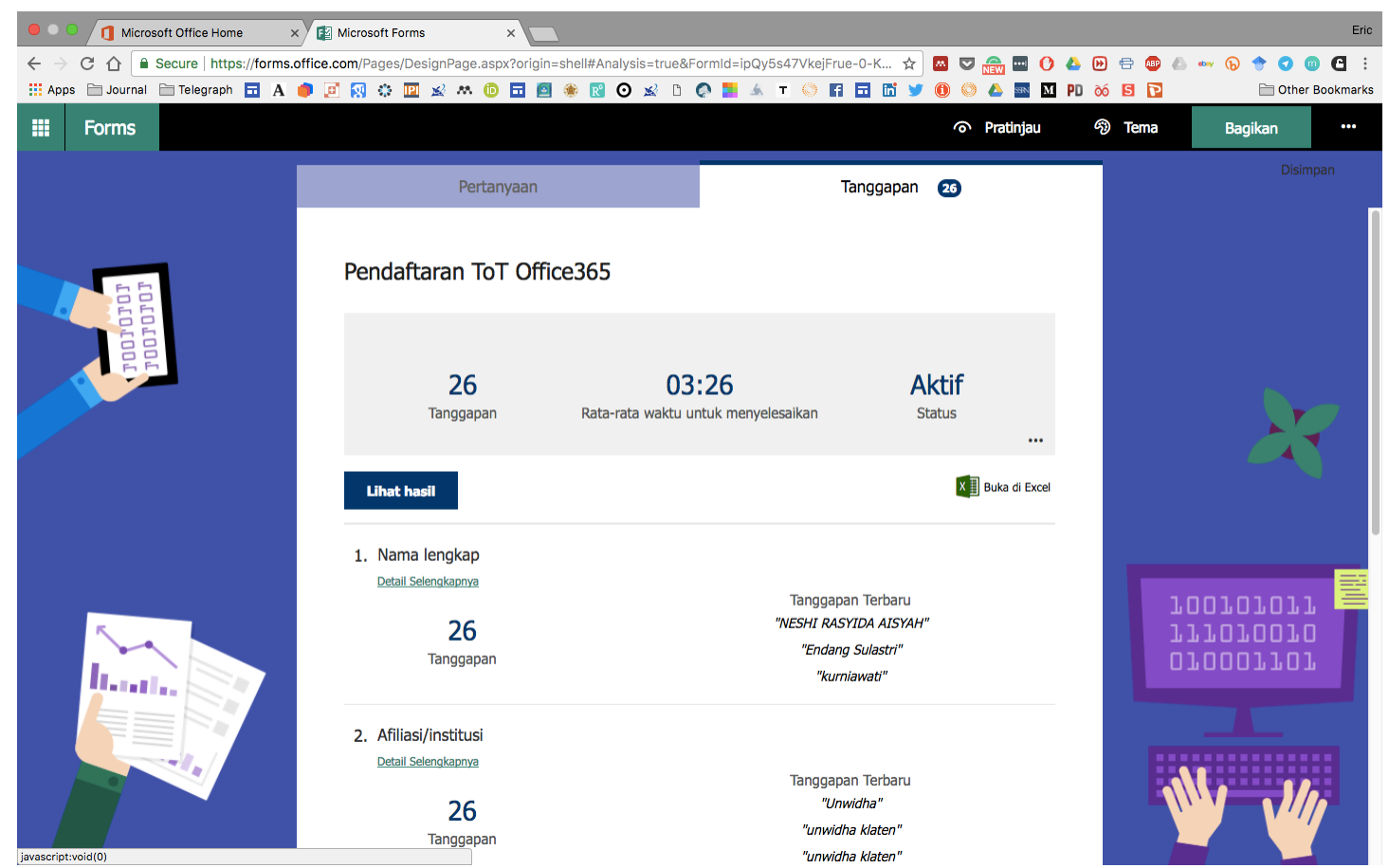


20. Untuk membuat kuis, Anda dapat melakukan hal serupa hanya ada beberapa opsi yang perlu diperhatikan, terutama terkait skor atau nilai apabila jawaban yang dipilih responden benar. Dalam konteks kuis, kita akan menambahkan pertanyaan berikut jawaban yang benar. Secara otomatis, sistem akan memcocokkan data dari input responden dengan jawaban kuci yang telah kita buat sebelumnya. Jawaban akan benar bilamana jawaban yang dimasukkan sama persis dengan jawaban kunci. Kolom poin adalah skor responden apabila menjawab pertanyaan dengan benar.

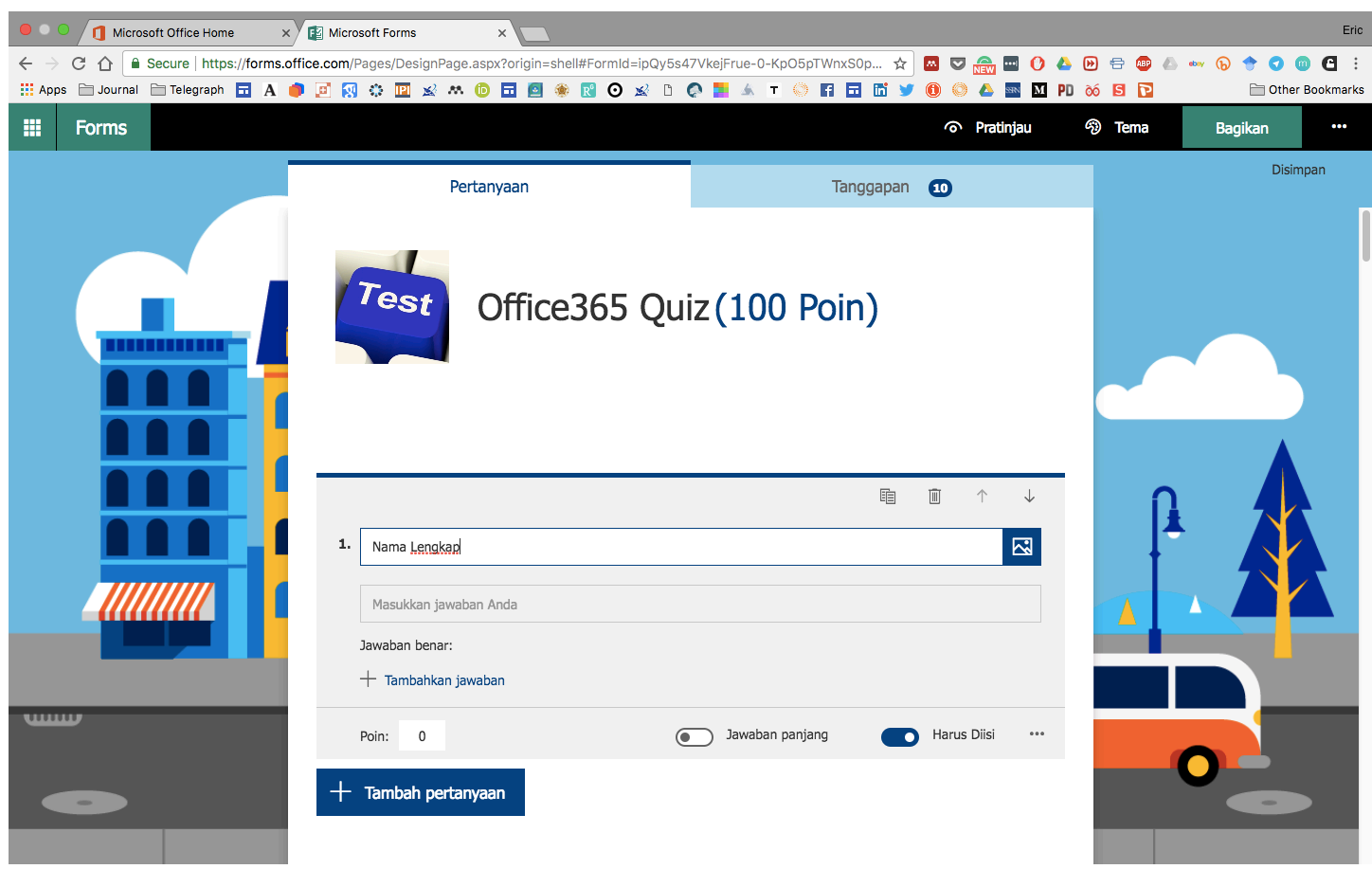

21. Masukkan pertanyaan dan alternatif jawaban. Untuk memilih jawaban yang benar (pada tipe soal pilihan) silakan klik di sebelah kanan jawaban yang Anda anggap benar.

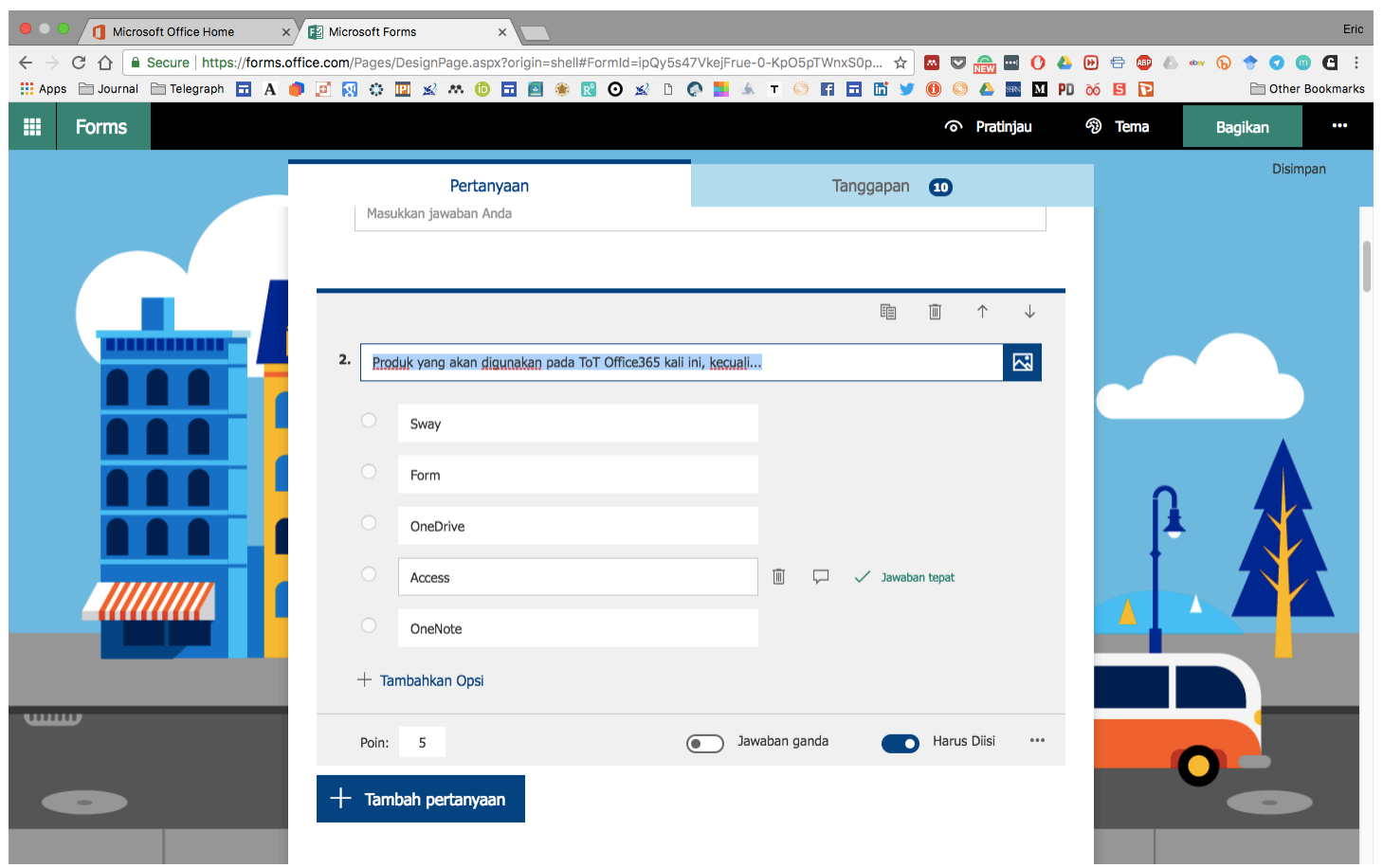


22. Untuk model soal dengan beberapa pilihan jawaban, Anda dapat mengaktifkan opsi "Jawaban ganda" kemudian memilih jawaban-jawaban yang benar.

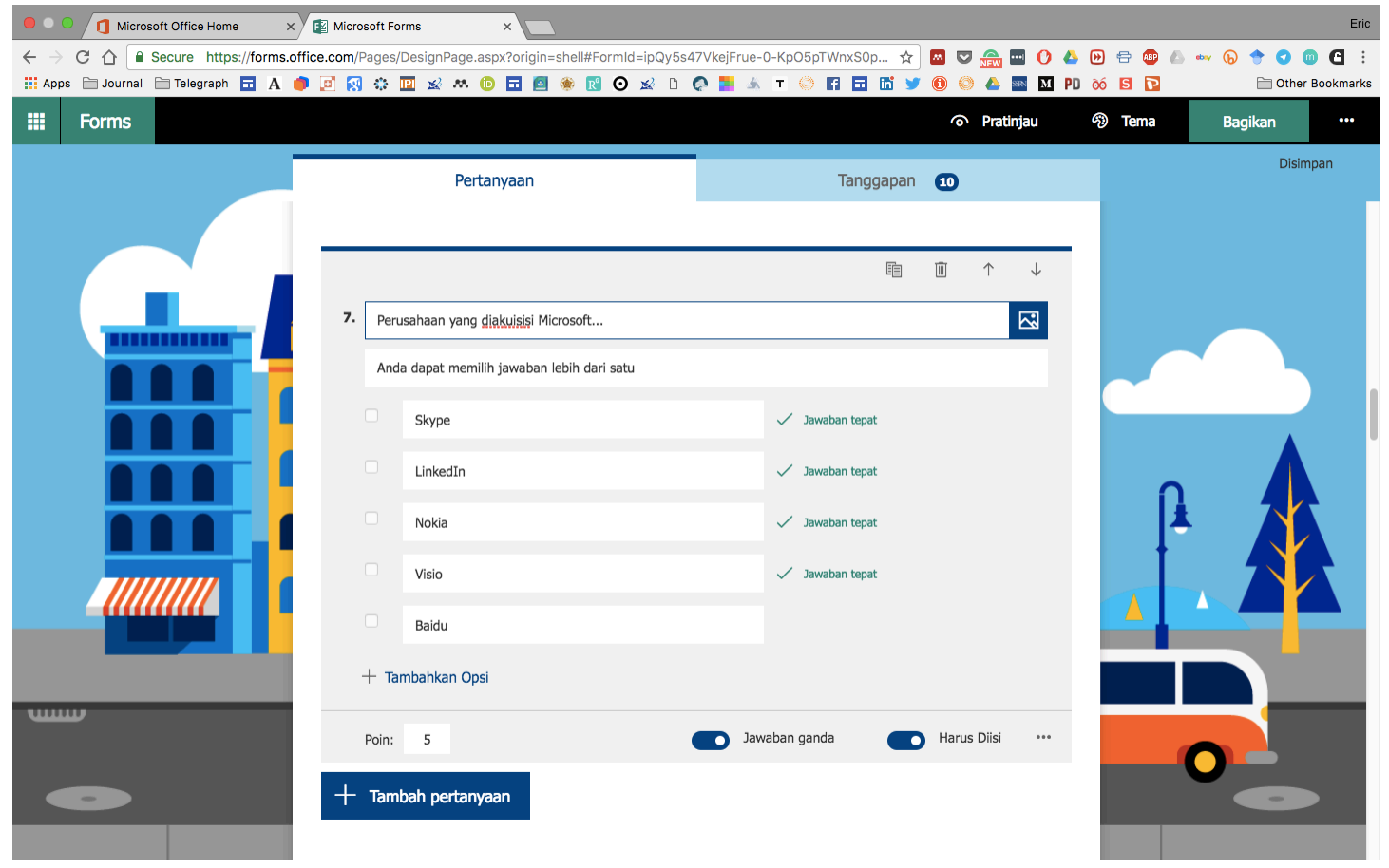

23. Hasil tanggapan pada kuis sedikit berbeda dengan formulir biasa (tanpa skor).

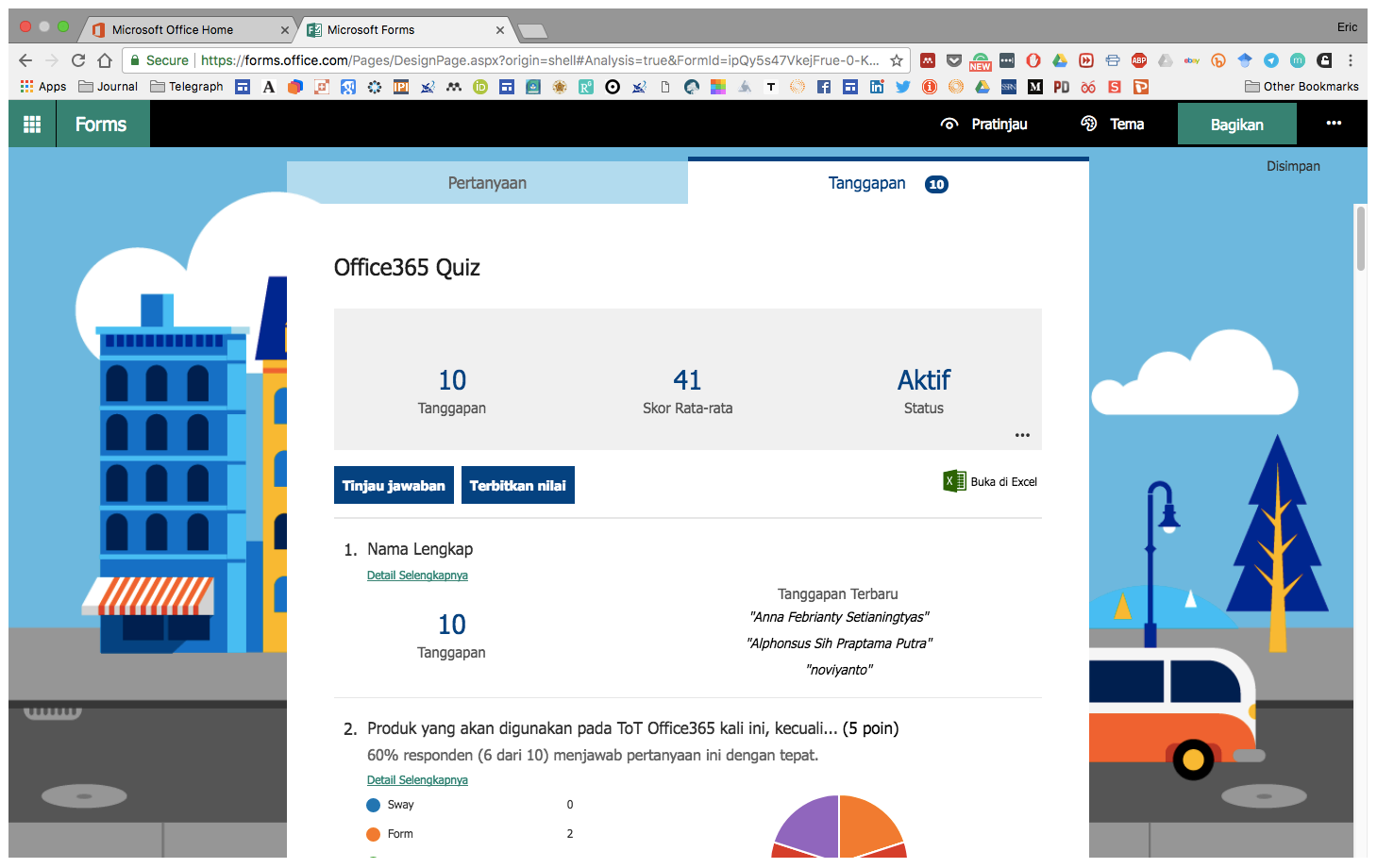


24. Untuk melakukan pengecekan jawaban (misalnya ada beberapa soal essai yang harus diperiksa secara manual) pilih opsi "Tinjau jawaban".

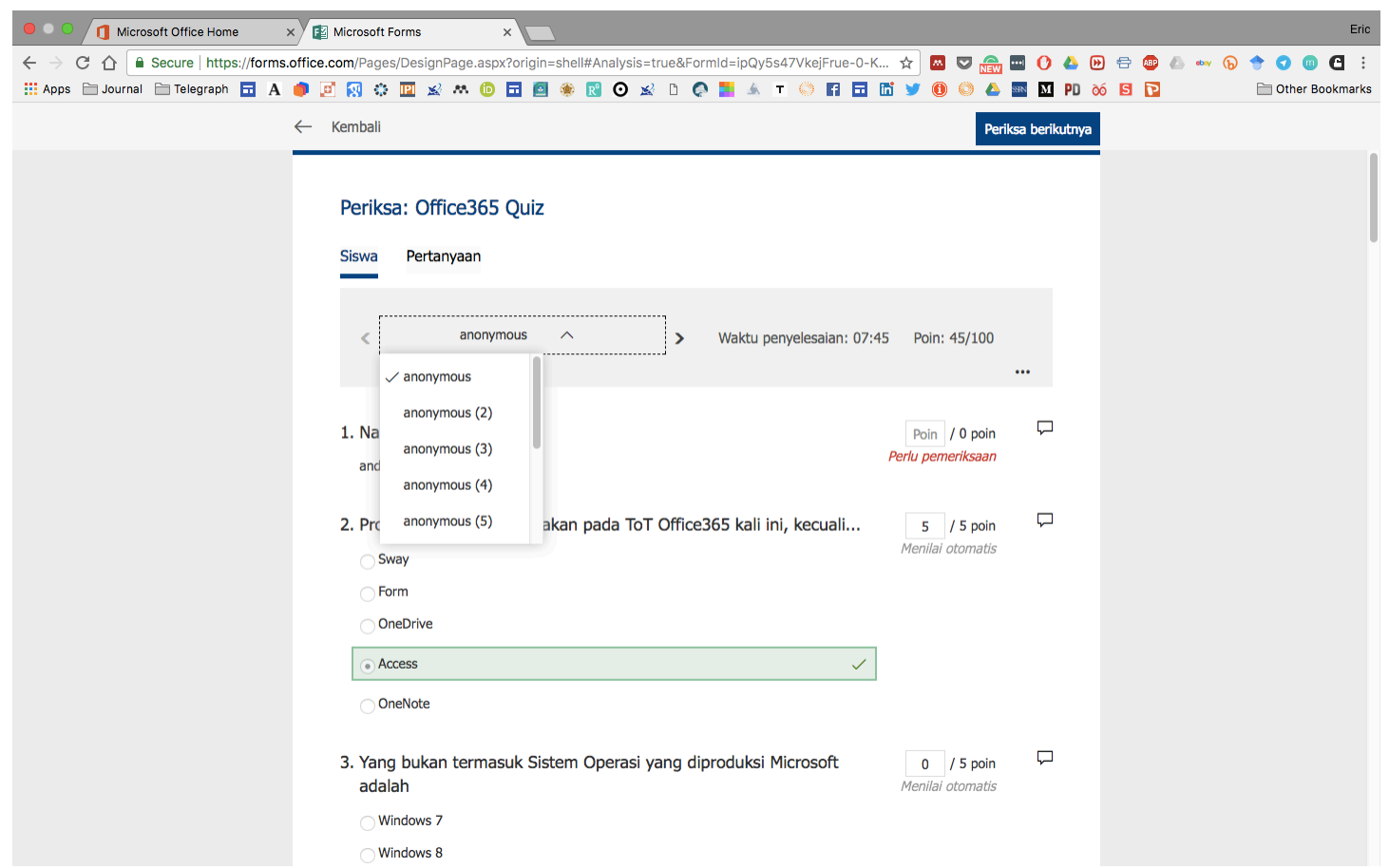

25. Secara otomatis, sistem akan mengoreksi jawaban yang diinput oleh responden. Jawaban benar berwarna hijau dan jawaban yang kurang tepat berwarna merah.

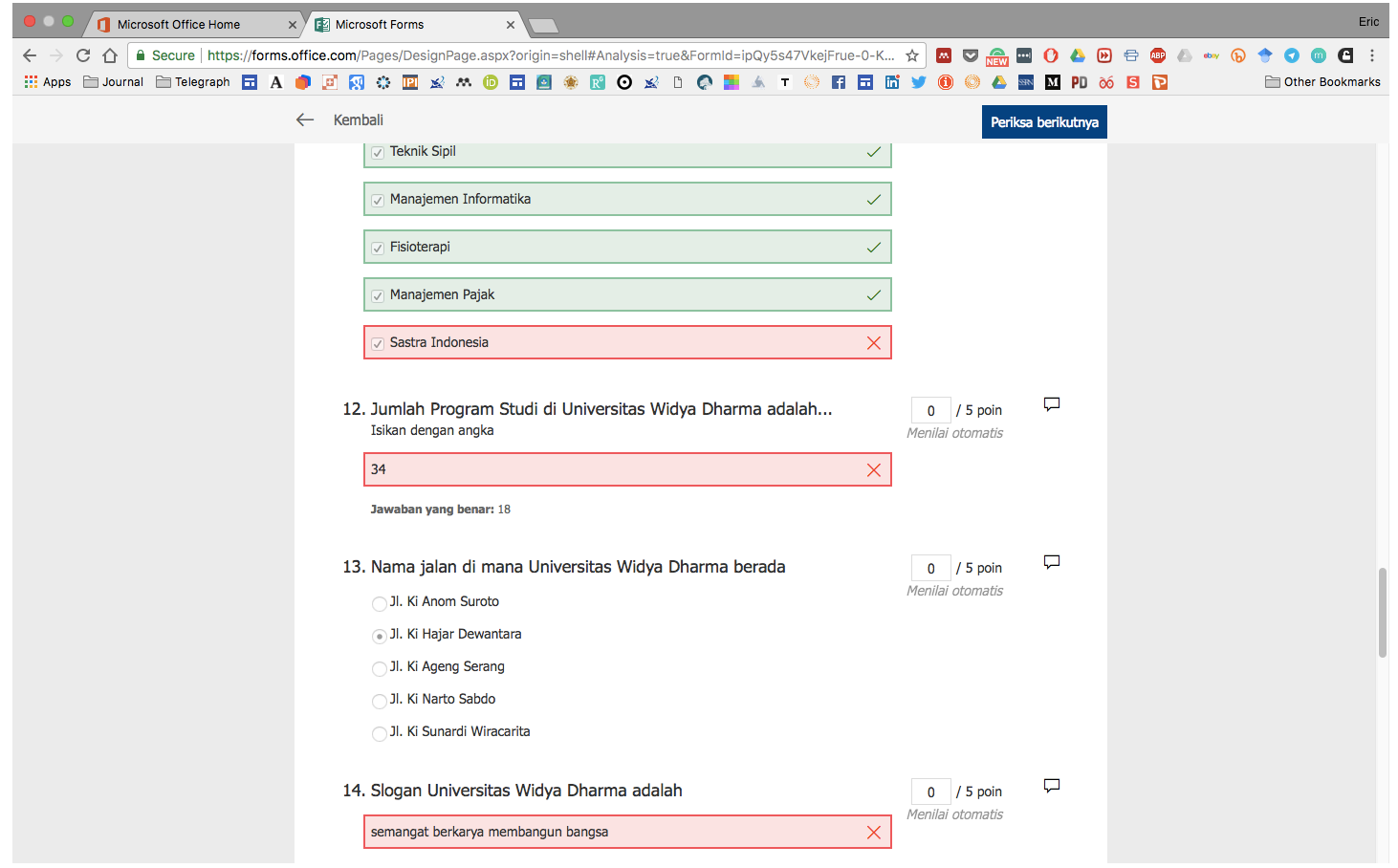


26. Skor secara otomatis akan diakumulasikan. Lihat bagian kanan atas. 45/100 artinya responden tersebut memperoleh 45 poin dari total 100 poin.

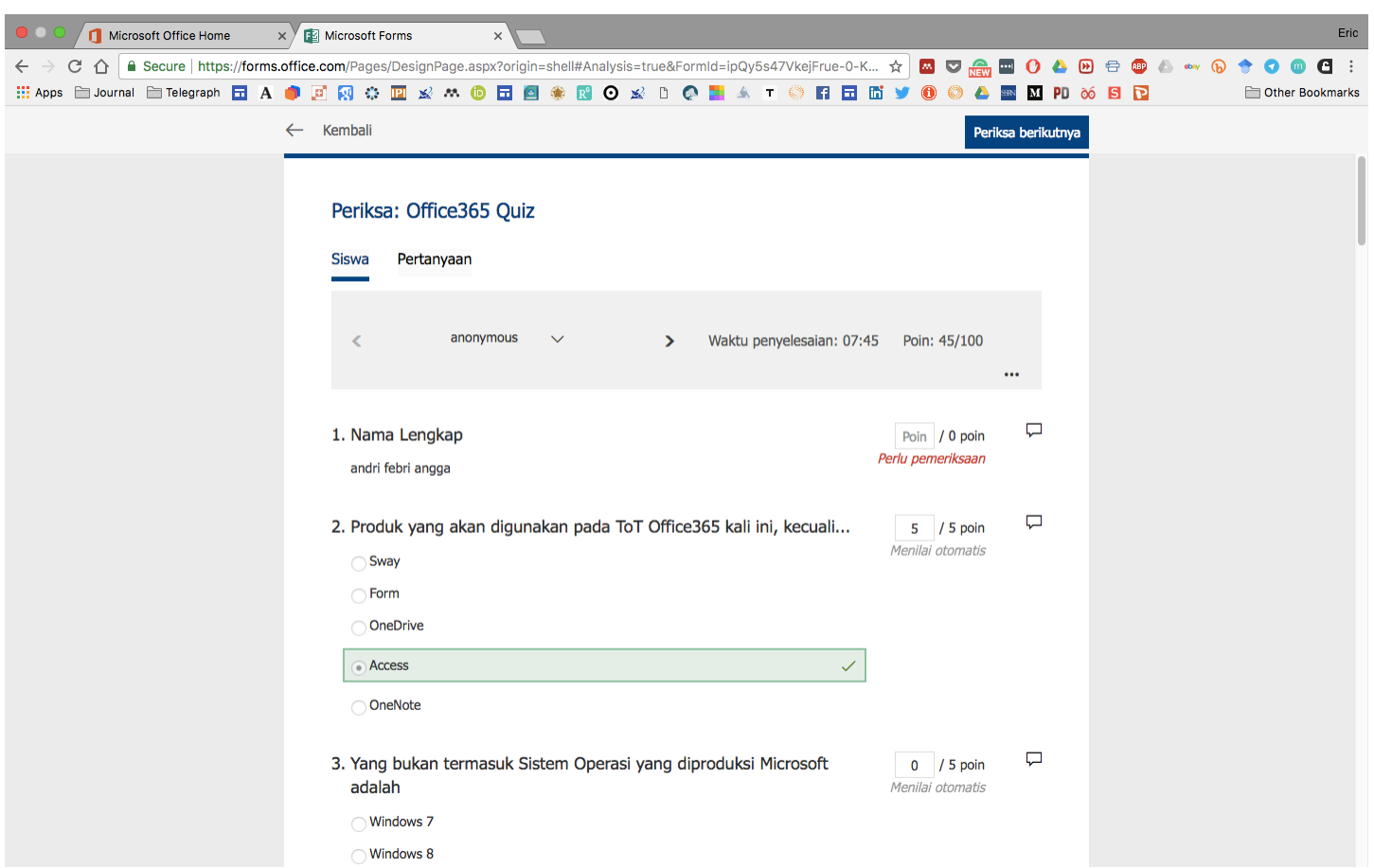




\section{TUGAS}

1. Buatlah sebuah formulir pendaftaran lomba, pendaftaran seminar atau jajak pendapat dengan menggunakan Form! Pertanyaan terdiri dari 10 item atau lebih dengan memanfaatkan seluruh tipe soal (Pilihan, Teks, Peringkat, Tanggal, Urutan).

2. Buatlah sebuah kuis, UTS, atau UAS dengan memanfaat Form yang terdiri dari minimal 20 soal! Buatlah poin dengan maksimal 100 apabila jawaban sepenuhnya terjawab!

3. Mintalah rekan Anda untuk mengisi kemudia publikasikan hasilnya! 